\title{
O RECORTE E A COSTURA DE ROMANCES-FOLHETINS EM PERIÓDICOS DA BELÉM DO SÉCULO XIX
}

\author{
Alan Victor Flor da Silva \\ Germana Maria Araújo Sales \\ UFPA
}

RESUMO: Segundo Anne-Marie Thiesse, a prática de recorte e costura dos fascículos de romances publicados no rodapé da página de jornais por leitores da França no século XIX foi legítima e recorrente. No Brasil, não encontramos ainda pesquisas a respeito dessa prática de apropriação do romancefollhetim por leitores brasileiros no Oitocentos. A partii, no entanto, da própria disposiçẫo das narrativas ficcionais nas folhas e nas colunas dos periódicos, objetivamos, com este trabalho, verificar se os leitores de jornais belenenses oitocentistas, assim como os franceses, poderiam fazer uso dessa técnica de recorte e costura dos fascículos de folhetins para fabricar formas rudimentares de livros.

PALAVRAS-CHAVE: Romance-folhetim. Práticas de leitura. Belém. Século XIX.

\section{CUTTING AND SEWING OF SERIAL NOVELS IN PERIODICALS OF $19^{\text {th }}$ CENTURY BELÉM}

ABSTRACT: According to Anne-Marie Thiesse, the practice of cutting and sewing of the instalments of novels published in the footer of newspaper pages by French readers in the nineteenth century was recurring and legitimate. In Brazil, we have not found research on this practice of appropriation of the serial novel by Brazilian readers in the nineteenth century. However, through the very disposition of fictional narratives in pages and columns of the periodicals, the purpose of this article is to verify that the readers of newspapers from Belém in the nineteenth century, just like the French, could make use of this cutting and sewing technique of instalments of serial novels to manufacture rudimentary forms of books.

KEYWORDS: Serial novels. Reading practices. Belém. Nineteenth century.

Alan Victor Flor da Silva é doutorando do Programa de Pós-Graduação em Letras da Universidade Federal do Pará.

Germana Maria Araúio Sales é professora do Instituto de Letras e Comunicação da Universidade Federal do Pará. 


\title{
O RECORTE E A COSTURA DE ROMANCES-FOLHETINS EM PERIÓDICOS DA BELÉM DO SÉCULO XIX ${ }^{1}$
}

\author{
Alan Victor Flor da Silva \\ Germana Maria Araújo Sales
}

PARA INÍCIO DE CONVERSA...

É inegável a presença maciça de romances-folhetins no rodapé das páginas de diversos jornais não apenas da Europa como também da América Latina. Como havia um número expressivo dessas publicações nas páginas dos jornais, é possível inferirmos, portanto, que esse gênero caiu no gosto dos leitores daquela época, sobretudo pelo fato de que o suporte em que era impresso foi responsável por popularizá-lo, uma vez que o preço dos jornais era muito mais acessível aos consumidores do que o do livro.

Segundo Roger Chartier, o significado de um texto depende das formas de apropriação, tomando como princípio básico o fato de que os leitores não se defrontam jamais com textos abstratos, ideais e desprovidos da materialidade onde são impressos, como os códices, os jornais, as revistas, os panfletos, entre outros. ${ }^{2}$ Chartier afirma ainda que "a leitura é sempre uma prática encarnada em gestos, em espaços, em hábitos". ${ }^{3}$ Desse modo, percebemos que o autor não concebe a leitura apenas como um ato de intelecção textual, mas também como uma atividade concreta no mundo que envolve tudo que gira ao redor do ato de ler. O suporte, portanto, é responsável pelos sentidos e pelas formas de apropriação atribuídas aos escritos, de tal modo que é possível assegurarmos, por exemplo, que leitura de um romance em livro não é a mesma quando ocorrida no jornal.

Nesse sentido, o romance, quando passa a ser publicado no início do século

\footnotetext{
${ }^{1}$ Este trabalho apresenta ainda os resultados parciais da pesquisa que estamos desenvolvendo sobre a prática de recorte e costura de fascículos de romances publicados no rodapé da página de periódicos belenenses oitocentistas para a fabricação de formas rudimentares de livro.

${ }^{2}$ CHARTIER, Roger. A ordem dos livros: leitoras, autores e bibliotecas na Europa entre os séculos XIV e XVIII. Trad. Mary Del Priori. Brasília: Editora da Universidade de Brasília, 1999.

${ }^{3}$ Ibidem, p. 13.
} 
XIX em jornais, sobretudo no espaço do rodapé da página, faz com que os leitores se apropriem dele de uma maneira diferente. Nesse sentido, em razão da mudança de suporte e, consequentemente, das novas formas de apropriação, das estratégicas técnicas de produção e de determinadas transformações estruturais, o romance divulgado em regime seriado nas páginas de algumas foIhas jornalísticas torna-se uma variante do gênero romanesco e, consequentemente, passa a ser chamado de romance-folhetim.

Sobre as formas de apropriação desse novo gênero criado por Émile de Girardin, Anne-Marie Thiesse, a partir de entrevistas que realizou no final do século XX com pessoas que viveram na França durante o período da Belle Époque, remonta uma prática concreta de leitura comum aos leitores de romancefolhetim: a fabricação de pequenos volumes de romances a partir de pedaços de jornais. ${ }^{4}$

Sabemos que os romances-folhetins eram publicados no rodapé da página dos jornais e separados do resto da folha por uma linha horizontal contínua. Diferentemente das outras seções, o Folhetim era a única coluna que apresentava essa peculiaridade. Ao considerarmos que o espaço geográfico do jornal destinado à publicação de romances-folhetins tenha sido acidental, podemos inferir que os leitores se prevaleceram dessa localização específica das narrativas em série lançadas no rodapé da página. Segundo Anne-Marie Thiesse, alguns leitores da França do século XIX, considerando que o lugar onde fascículos dos romances-folhetins eram divulgados consistia em um espaço favorável ao recorte, podiam facilmente retalhá-los e desfazerem-se posteriormente do restante do jornal. Em seguida, a partir de operações de recorte e costura sobre a base da página, juntavam todos os fascículos dos romances e elaboravam uma forma rudimentar de livro. Assim, podiam guardá-los para relê-los depois, emprestá-los aos amigos ou lê-los em voz alta nos serões. ${ }^{5}$

\footnotetext{
${ }^{4}$ Cf. THIESSE, Anne-Marie. Le roman au quotidian: lecteurs et lectures populaires à Belle Époque. Paris: Éditions du Seuil, 2000.

${ }^{5}$ Segundo a bibliografia sobre o folhetim, a coluna localizada no rodapé da página dos jornais antecedeu a publicação do gênero folhetinesco. Émile de Girardin, editor do jornal La Presse e o grande empreendedor da publicação de ficção em série, ganhou notoriedade apenas porque aproveitou-se de um gênero literário e de um suporte material que preexistiam ao romance-folhetim. Desse modo, podemos afirmar que o rodapé não foi um espaço geográfico estratégico para que os leitores pudessem recortá-lo e posteriormente apropriar-se dele da maneira como bem o quisessem. Sobre essa questão, Roger Chartier defende que o suporte é responsável pelo surgimento de novas práticas de leitura. Nesse sentido, é possível percebermos que foram os leitores que passaram a tomar consciência de que a localização geográfica do espaço folhetim lhes permitia a prática concreta do recorte e da costura dos fascículos
} 
Ao considerar algumas questões relacionadas ao ato de ler, Michel de Certeau afirma que a leitura, em contraste com o escrito, encontra-se na ordem do efêmero e, por essa razão, raramente deixa marcas, pistas ou vestígios. ${ }^{6}$ Desse modo, é difícil sabermos se, de fato, os leitores de jornais brasileiros do século XIX adotaram como prática concreta de leitura o recorte e a costura de fascículos de romances publicados no rodapé da página. Ubiratan Machado, por exemplo, é o único autor brasileiro que se remete a essa prática de leitura no Brasil.7 Segundo o autor, os romances de José de Alencar publicados apenas em livro pela editora Garnier foram um verdadeiro sucesso editorial, como Lucíola e Diva. O romance $O$ Guarani, no entanto, ao ser publicado em livro, não repetiu o mesmo sucesso de quando foi lançado em folhetim, em 1857, no jornal Diário do Rio de Janeiro. Para justificar esse episódio, Ubiratan Machado levanta a hipótese de que, quando um romance publicado na imprensa se tornava um verdadeiro sucesso editorial, os leitores recortavam os capítulos e guardavamnos em casa para serem relidos, emprestados aos amigos ou lidos em serões. Desse modo, o romance indianista de Alencar, segundo Ubiratan Machado, não teve êxito de vendas ao ser lançado em livro, pois os leitores já o haviam lido em folhetim, fato que inviabilizava a aquisição da obra em qualquer outro suporte. É importante, porém, ressaltarmos que, embora a hipótese de Ubiratan Machado seja em certa medida aceitável, o autor não apresenta fontes que confirmem a concretização dessa prática de leitura no Brasil.

A partir, no entanto, da própria disposição das narrativas nas folhas e nas colunas dos periódicos, objetivamos, com este trabalho, verificar se os leitores de jornais belenenses oitocentistas, assim como ocorria com os franceses do mesmo período, poderiam fazer uso dessa técnica de recorte e costura dos fascículos de folhetins para fabricar formas rudimentares de livros. Para tanto, verificaremos a disposição dessas narrativas em regime seriado divulgadas no jornal A Província do Pará durante o século XIX (1876-1900).

das narrativas folhetinescas para a fabricação de formas elementares de livros. Cf. CHARTIER, Roger. A ordem dos livros: leitoras, autores e bibliotecas na Europa entre os séculos XIV e XVIII , op. cit.

${ }^{6}$ CERTEAU, Michel de. Ler: uma operação de caça. In: A invenção do cotidiano: 1. Artes de fazer. 20. ed. Trad. Ephraim Ferreira Alves. Petrópolis: Vozes, 2013.

7 Cf. MACHADO, Ubiratan. A vida literária durante o Romantismo. 2. ed. Rio de Janeiro: Tinta Negra Bazar Editorial, 2010. 
O JORNAL A PROVÍNCIA DO PARÁ: UMA BREVE HISTÓRIA...

A publicação de narrativas no rodapé da página de periódicos era uma prática comum no Brasil do século XIX. Essa técnica não se restringiu apenas ao Rio de Janeiro, mas também a outras províncias difundidas por todo o território nacional. Pesquisas apontam que o gênero folhetinesco não somente circulou, como ainda fez um grande sucesso entre o público-leitor em outras regiões do país, como no Mato Grosso, no Rio Grande do Sul, no Pará e na Paraíba. ${ }^{8}$

Na província do Pará do século XIX, diversos periódicos se dedicaram à publicação de narrativas ficcionais em regime seriado, como Diário do Gram-Pará, Diário de Belém, O Liberal do Pará, Folha do Norte, Jornal do Pará e A Província do Pará. Muitas vezes, ficcionistas estrangeiros - sobretudo da Europa (franceses, portugueses, espanhóis etc.) - e nacionais - da Amazônia ou de outras localidades do território nacional - tornavam-se conhecidos por meio da veiculação de suas obras em páginas de jornais que circulavam na capital ou em outras partes da província.

Segundo Carlos Rocque, circulavam apenas na cidade de Belém do século XIX aproximadamente 150 periódicos. ${ }^{9}$ Considerando que a capital paraense era pequena, tinha à época apenas noventa mil habitantes e apresentava um índice muito alto de analfabetismo, essa estimativa gera uma grande surpresa. Devemos considerar, no entanto, que muitos desses periódicos tiveram um tempo de vida efêmero e não chegaram a circular por mais de um ano. Alguns tiveram apenas um único número, pois foram lançados exclusivamente para comemorar uma data ou um fato importante ou para defender uma causa política ou religiosa. Se considerarmos apenas os periódicos que circularam por um longo período por Belém durante o século XIX, a estimativa de Carlos Rocque consideravelmente diminui, pois foram poucos os jornais paraenses que chegaram a completar, por exemplo, uma década de circulação, como Diário do

\footnotetext{
8 Sobre a circulação de folhetins em jornais do Mato Grosso, cf. NADAF, Yasmin Jamil. Rodapé das miscelâneas: o folhetim nos jornais de Mato Grosso (séculos XIX eXX). Rio de Janeiro: 7Letras, 2002; a respeito da presença de romances-folhetins na imprensa periódica do Rio Grande do Sul, cf. HOHLFELDT, Antonio. Deus escreve direito por linhas tortas: O romance-folhetim dos jornais de Porto Alegre entre 1850 e 1900. Porto Alegre: EDIPUCRS, 2003; em relação à publicação de prosa de ficção em periódicos belenenses oitocentistas, cf. SALES, Germana Maria Araújo. Folhetins: uma prática de leitura no século XIX. Entrelaces, v. 1, p. 44-56, 2007; no que se refere à divulgação de folhetins paraibanos no século XIX, cf. FORMIGA, Girlene Marques; SILVA, Fabiana Sena da; BARBOSA, Socorro Pacífico (Org.). Miscelâneas, rodapés e variedades: antologia de folhetins paraibanos do século XIX. João Pessoa: Ideia Editora, 2007

${ }^{9}$ ROQUE, Carlos. História geral de Belém e do Grão-Pará. Belém: Distribel, 2001.
} 
Gram-Pará, Diário de Belém, O Liberal do Pará, Folha do Norte, Jornal do Pará e A Província do Pará.

Se já é difícil encontrarmos uma folha jornalística que tenha completado uma década de existência, é mais raro ainda nos depararmos com um jornal que tenha comemorado o seu centenário de vida. Na cidade de Belém, A Província do Pará foi o único periódico que conseguiu atingir essa façanha.

O jornal A Província do Pará ocupa um lugar de destaque na história da imprensa periódica belenense. Segundo Carlos Rocque, foi o centésimo quadragésimo quinto periódico a ser lançado na capital paraense e o sexto de circulação diária. ${ }^{10} \mathrm{~A}$ história dessa folha jornalística divide-se em quatro fases. Esse periódico saiu à luz no dia 25 de março de 1876, iniciando a sua primeira fase, e foi um jornal de circulação diária, fundado por Joaquim José de Assis (redator político), Francisco de Souza Cerqueira (tipógrafo) e Antônio José de Lemos (redator-gerente). Inicialmente, foi órgão do Partido Liberal até 1889 e depois se tornou independente e imparcial em política, passando a ser uma empresa comercial. No dia 10 de abril de 1897, após a morte dos demais sócios, Antônio José de Lemos associa-se ao grupo Chermont, representado por Pedro Chermont. Por desentendimento entre os sócios, em novembro de 1900, foi interrompida a publicação do jornal, encerrando, assim, a sua primeira fase.

Reiniciou a segunda fase no dia $1^{\circ}$ de maio do ano seguinte, quando Antônio Lemos indenizou os demais sócios e tornou-se o único proprietário. Em 29 de agosto de 1912, as instalações do jornal, no entanto, foram incendiadas pelos inimigos políticos do intendente, provocando o final da segunda fase.

Mais tarde, no dia 6 de julho de 1920, sob a direção de Pedro Chermont de Miranda e sob a redação de João Batista Ferreira de Souza, o jornal A Província do Pará recomeçou a sua publicação, iniciando, dessa maneira, sua terceira fase. No dia 27 de julho de 1926, a circulação do jornal é novamente suspensa, dessa vez em razão de problemas financeiros.

No dia 6 de fevereiro de 1947, os Diários Associados, dirigidos por Assis Chateaubriand, adquiriram o jornal paraense, dando início à sua quarta e última fase, agora sob a direção de Milton Trindade, Roberto Jares Martins e Artêmio Guimarães. A partir da década de 1980, as dívidas, o atraso tecnológico, a perda de leitores e de anunciantes, porém, conduziriam o jornal para um novo período

\footnotetext{
${ }^{10}$ Idem, História de A Província do Pará. Belém: Editora Mitograph, 1976.
} 
de decadência. O periódico ainda passou pelas mãos de dois outros proprietários - o editor de livros Gêngis Freire e o publicitário Miguel Ângelo Arraes antes de encerrar definitivamente as suas atividades no ano de 2001, quando já estava falido e desacreditado. Apesar das crises sucessivas, foi o jornal que circulou por mais tempo no estado do Pará: aproximadamente 125 anos.

Durante o século XIX, esse periódico publicou diversos gêneros literários, como a crônica, a poesia, o conto, o romance e, sobretudo, o romance-folhetim. Esses gêneros eram muitas vezes divulgados em diversas seções: Folhetim; Ciências, Letras e Artes; Artes e Letras; Miscelânea; Variedade; Literatura e As noites amazônicas ${ }^{11}$. Nesses espaços, obras de escritores tanto nacionais quanto estrangeiros (sobretudo franceses, portugueses e espanhóis) eram ofertadas aos leitores do jornal A Província do Pará.

Os folhetinistas franceses eram os mais assíduos entre os escritores estrangeiros. Nomes como os de Jorge Ohnet, Xavier de Montépin, Ponson du Terrail e Paul Féval eram muito recorrentes nas páginas do periódico belenense oitocentista. Além de escritores franceses, publicações assinadas por autores de outras nacionalidades também foram divulgadas nas páginas do jornal A Província do Pará. Entre os portugueses, os que mais se destacaram, sobretudo como contistas, foram Eça de Queirós, Pinheiro Chagas e Alexandre Herculano. Entre os espanhóis, os mais assíduos folhetinistas foram Manuel Fernández y González, Ortega y Frias, Rafael del Castillo e Manuel Juan Diana.

Os escritores brasileiros, geralmente, eram naturais da região amazônica. Embora fossem poucos, contribuíram com textos em prosa de ficção para a imprensa periódica belenense oitocentista, sobretudo com narrativas curtas, divulgadas geralmente em apenas um único fascículo. Marques de Carvalho, Juvenal Tavares, Paulino de Brito, Múcio Javrot, Antônio de Carvalho, José Veríssimo, Frederico Rhossard e João Pontes de Carvalho são alguns nomes de escritores que aparecem nas páginas do jornal A Província do Pará.

${ }^{11}$ A seção As noites amazônicas é uma variante da coluna Folhetim, pois ambas se localizam no rodapé da página do jornal separadas das demais por uma linha horizontal e se destinam a divulgar prosa de ficção. A primeira, no entanto, restringe-se a publicar exclusivamente produções de autores amazônicos. 


\section{O RECORTE E A COSTURA DE ROMANCES-FOLHETINS NO JORNAL A PROVÍNCIA DO PARÁ}

Segundo Anne-Marie Thiesse, a prática de recorte e costura dos fascículos de romances publicados no rodapé da página de jornais por leitores da França no século XIX foi legítima e recorrente, embora a autora afirme que "o resultado era muito frágil, de um valor estético medíocre". ${ }^{12}$ Porém, para que essa fabricação de formas rudimentares de livro a partir de pedaços de jornal se tornasse concreta, era necessário que a disposição da narrativa nas folhas jornalísticas se desse de uma maneira harmônica e regular em todos os fascículos. Desse modo, a linha horizontal que separa a coluna Folhetim das outras demais deveria sempre permanecer na mesma altura e cada fascículo do mesmo romance, por sua vez, precisaria começar no início da primeira coluna do rodapé e terminar no final da última. Para exemplificarmos como os romances-folhetins eram dispostos nas páginas da imprensa jornalística francesa, escolhemos o romance $L a$ comtesse de Monrion, de autoria do escritor francês Fréderic Soulié (18001847), publicado no jornal La Presse, entre os dias 9 de dezembro de 1845 e 22 de janeiro de 1846.

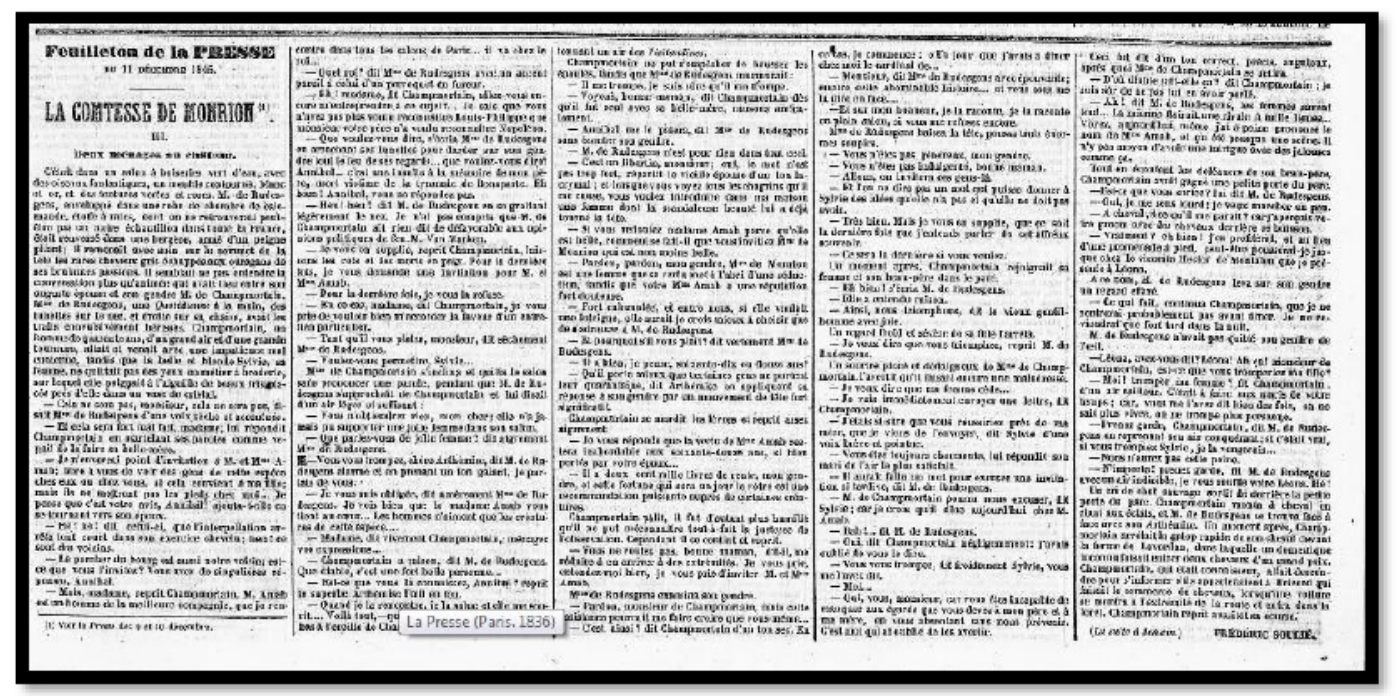

Figura 1 - terceiro fascículo do romance La comtesse de Monrion, de Fréderic Soulié, publicado na primeira página do jornal La Presse, no dia 11 de dezembro de 1845 Bibliothèque Nationale de France (BnF).

12 THIESSE, Anne-Marie. Le roman au quotidian: lecteurs et lectures populaires à Belle Époque. Paris: Éditions du Seuil, 2000, p. 20. (Tradução nossa). 
Divulgado em uma, duas e às vezes até mesmo em três páginas, os fascículos do romance de Soulié apresentam uma regularidade no regime de publicação, pois todos eles, independentemente do número de páginas que cada um tenha preenchido, ocuparam completamente o espaço do rodapé, desde a primeira coluna inteira até a última. Assim como acontece com o romance $L a$ comtesse de Monrion, muitas outras narrativas publicadas no jornal francês de Émile de Girardin, salvo algumas raríssimas exceções que se manifestaram de modo pouco expressivo, comportam-se dessa mesma maneira, mantendo a simetria entre todos os fascículos. Por essa razão, podemos afirmar que, de modo geral, a prática de recorte e de costura dos folhetins era muito viável para os leitores do jornal La Presse.

No jornal A Província do Pará, no entanto, a simetria e a assimetria na disposição das narrativas no rodapé convivem simultaneamente. Há romances, por exemplo, que ocupam todo o espaço geográfico destinado à base da página, assim como há outros cujos fascículos são publicados de forma muito irregular. Neste trabalho, apresentaremos duas obras de caráter folhetinesco lançadas no jornal A Província do Pará que ilustram os dois casos.

Para exemplificarmos como os fascículos dos romances-folhetins divulgados no rodapé da página da imprensa jornalística belenense oitocentista manifestam-se de maneira tanto regular quanto irregular, elegemos, para elucidarmos o primeiro caso, o romance Não é bom brincar com a dor, cuja autoria é atribuída a Madame Émile de Girardin, pseudônimo da escritora francesa Delphine de Girardin (1804-1855). Essa obra foi publicada entre os dias 12 de janeiro e 7 de março de 1877 e circulou no jornal A Província do Pará por aproximadamente dois meses. Para ilustrarmos, por sua vez, o segundo caso, selecionamos o romance inacabado $A$ leviana: história de um coração, do escritor brasileiro João Marques de Carvalho (1866-1910). Essa obra foi divulgada no periódico paraense em questão entre os dias 25 de março e $1^{\circ}$ de agosto de 1885 e circulou por quase quatro meses. ${ }^{13}$

Quanto ao primeiro exemplo, todos os fascículos do romance Não é bom brincar com a dor foram publicados na coluna Folhetim sempre à segunda página e ocupam ainda todas as cinco colunas, desde o início da primeira até o final da última. Essa disposição totalmente simétrica dos fascículos da narrativa

${ }^{13}$ Durante a catalogação da prosa de ficção do jornal A Província do Pará, encontramos vinte e dois fascículos do romance de Madame Émile de Girardin, Não é bom brincar com a dor, e trinta e oito do de Marques de Carvalho, A leviana: história de um coração. 
no rodapé, portanto, demonstra que a prática de recorte e costura a partir de folhas jornalísticas poderia muito bem ser exercida por algum leitor do jornal $A$ Província do Pará.

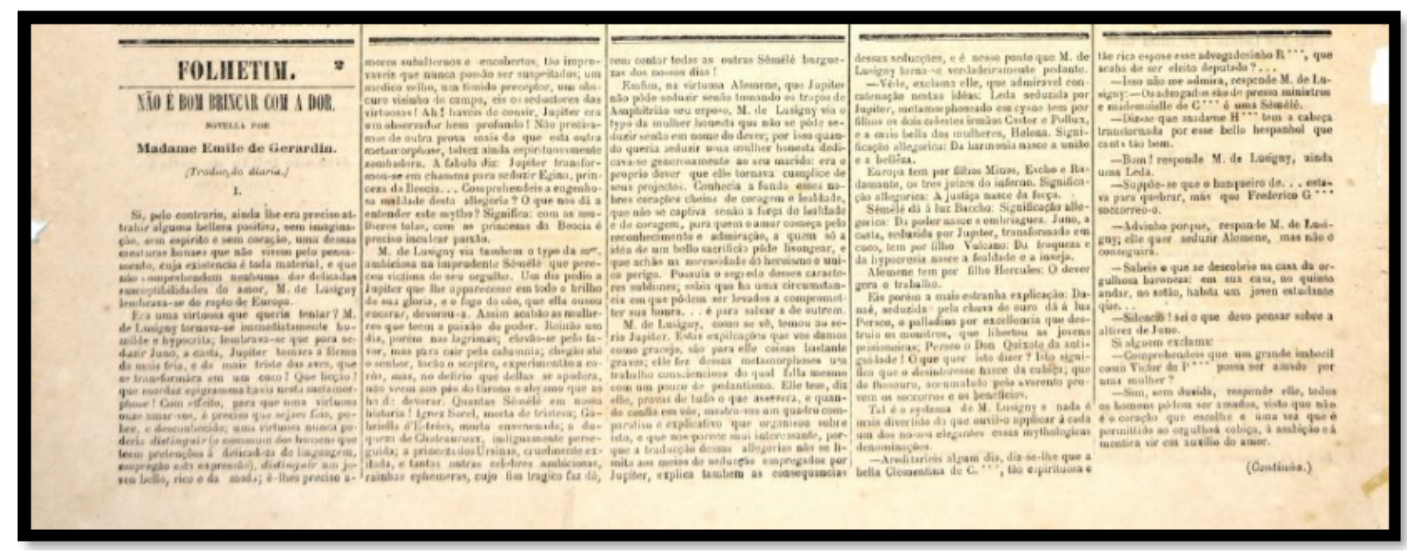

Figura 2 - Segundo fascículo do romance Não é bom brincar com a dor, de Madame Émile de Girardin, publicado na segunda página do jornal A Província do Pará, no dia 13 de janeiro de 1877 Fundação Cultural do Pará Tancredo Neves (FCPTN).

O segundo exemplo, por sua vez, revela uma total assimetria entre os fascículos do romance de Marques de Carvalho. Logo na estreia dessa publicação, o primeiro número da obra ocupa a segunda e a terceira página do jornal. $\mathrm{Na}$ segunda, todas as colunas são preenchidas, mas, na terceira, apenas a metade inicial da primeira coluna. Logo em seguida, outra narrativa passa a ser divulgada: o romance Andréa, cuja autoria foi atribuída ao escritor francês Georges Duruy (1853-1918). Essa obra vinha sendo divulgada pelo jornal A Província do Pará desde o dia 10 de fevereiro de 1885 e já se encontrava em seu trigésimo sétimo fascículo, quando o romance $A$ leviana: história de um coração começou a ser publicado. ${ }^{14}$

${ }^{11}$ É importante ressaltarmos que, quando o romance de Marques de Carvalho passou a ser publicado, as colunas do jornal A Província do Pará já haviam passado de cinco para seis por página. 

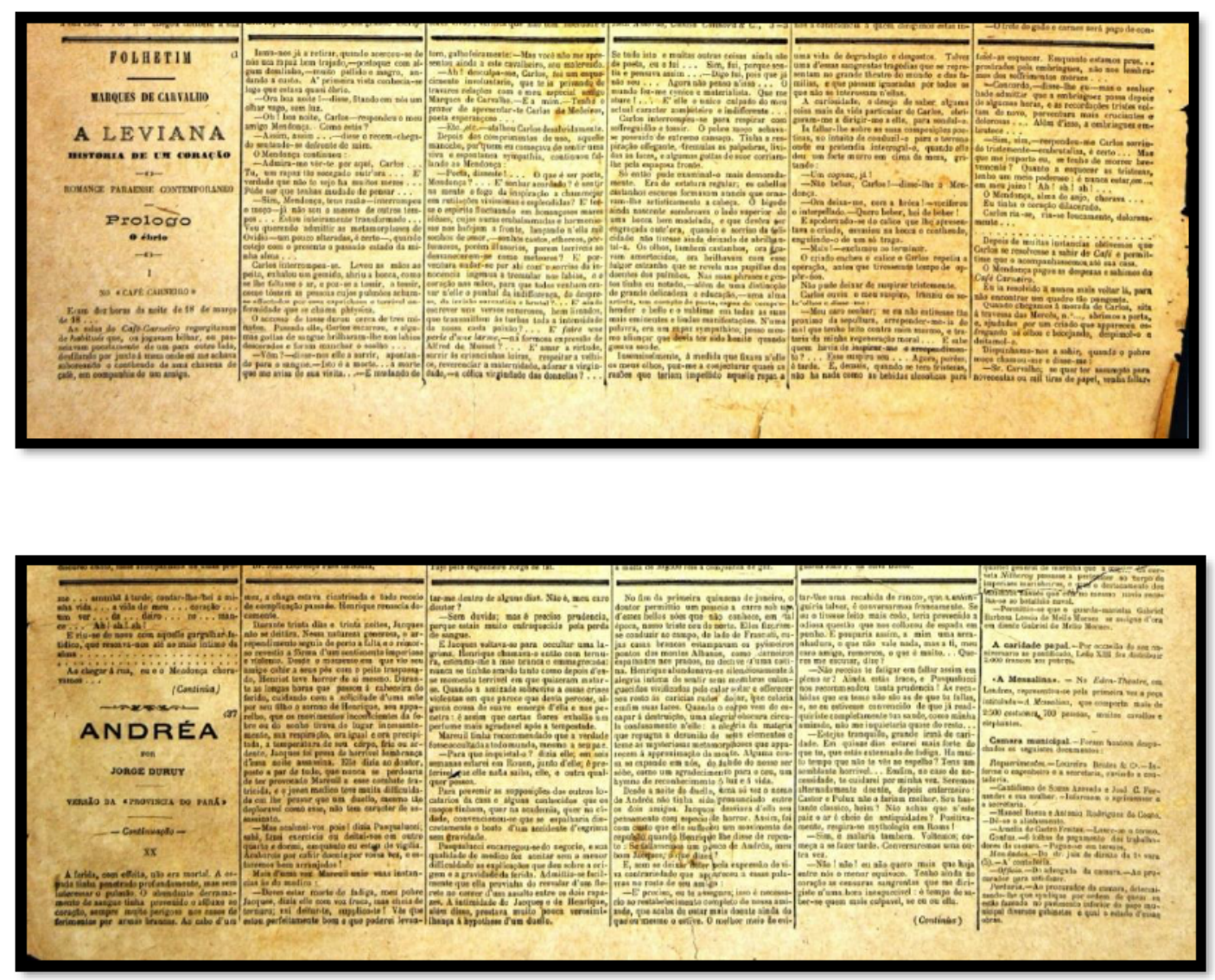

Figuras 3 e 4 - A coluna Folhetim do jornal A Província do Pará, localizada na segunda e terceira página, onde foram publicados os romances $A$ leviana: história de um coração, de Marques de Carvalho, e Andréa, de Georges Duruy, no dia 25 de março de 1885 Fundação Cultural do Pará Tancredo Neves (FCPTN).

O segundo número da obra de Marques de Carvalho, que saiu à luz no dia 27 de março de 1885, ocupou as três primeiras colunas inteiras da segunda página e a metade da quarta. O restante do espaço do rodapé, por sua vez, foi preenchido pelo romance de Georges Duruy. 


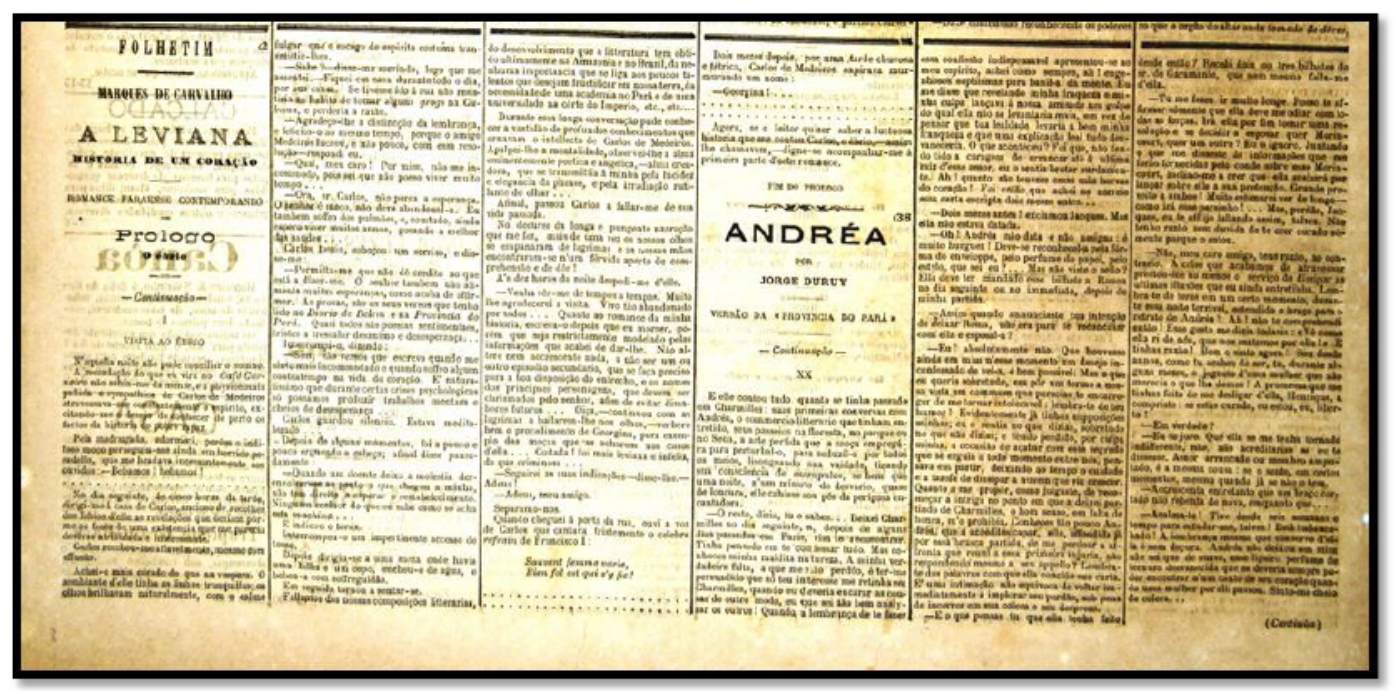

Figura 5 - A coluna Folhetim do jornal A Província do Pará, localizada na segunda página, onde foram publicados os romances A leviana: história de um coração,

de Marques de Carvalho, e Andréa, de Georges Duruy, no dia 27 de março de 1885

Fundação Cultural do Pará Tancredo Neves (FCPTN).

Até o dia 29 de abril de 1885, quando o romance de Georges Duruy, em sua sexagésima quarta aparição, chega ao seu último capítulo, a narrativa de caráter folhetinesco de Marques de Carvalho, todas as vezes em que algum fascículo dela era publicado, dividia o espaço do rodapé com a obra Andréa.

Embora o romance de Georges Duruy já tivesse sido concluído, no dia 5 de maio de 1885, outra narrativa, em alguns números do jornal A Província do Pará, passa a ser divulgada juntamente com a de Marques de Carvalho. Dessa vez, trata-se da obra Os Monach, de autoria do escritor francês Robert de Bonnières (1850-1905). 


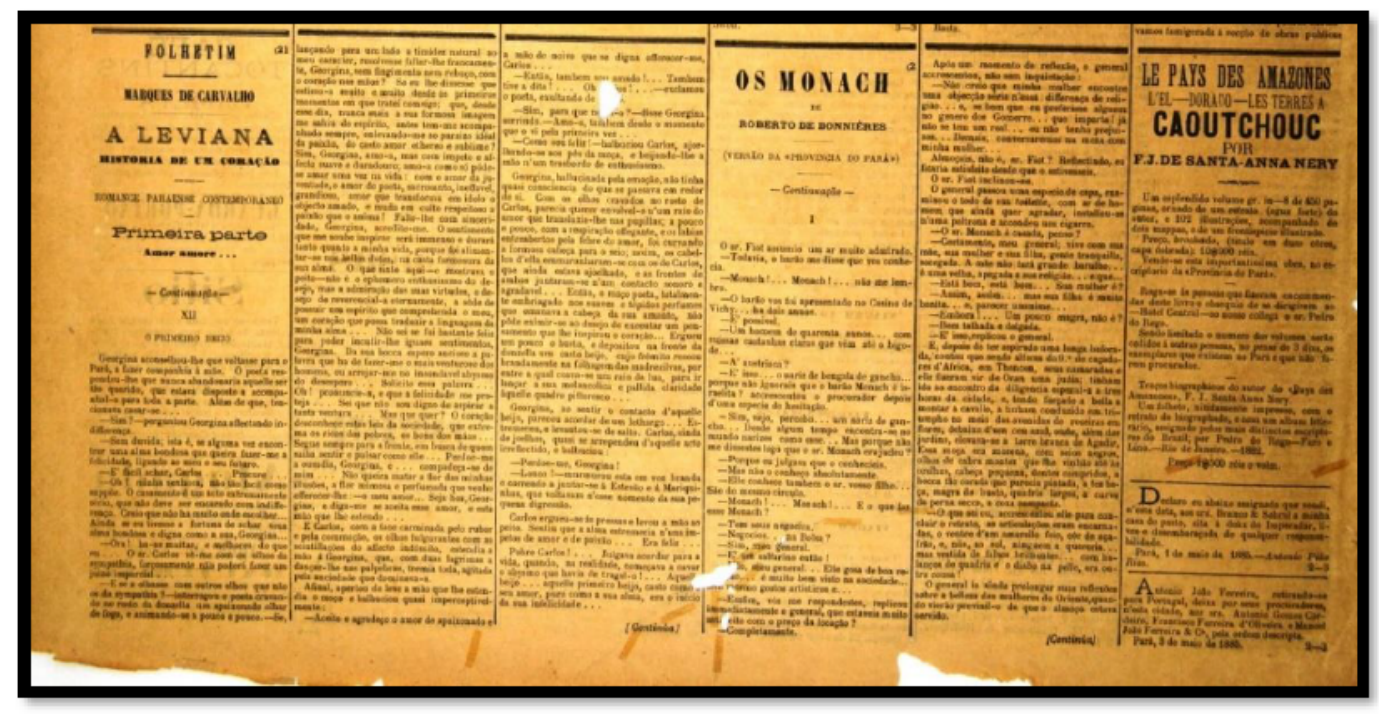

Figura 6 - A coluna Folhetim do jornal A Província do Pará, localizada na segunda página, onde foram publicados os romances $A$ leviana: história de um coração, de Marques de Carvalho, e Os Mocach, de Robert de Bonnières, no dia 5 de maio de 1885 Fundação Cultural do Pará Tancredo Neves (FCPTN).

O fato de dois ou mais romances serem divulgados ao mesmo tempo provocava uma consequência para o possível leitor do século XIX que tinha o hábito de recortar e costurar as narrativas publicadas no rodapé das páginas de alguns jornais. Esse leitor não pode mais compilar os fascículos de uma única obra sem que pedaços de uma outra não viessem acompanhados. Desse modo, não era possível que os presumíveis apreciadores do romance de Marques de Carvalho, por exemplo, reunissem os fragmentos dessa obra de uma maneira em que não estivessem presentes determinadas partes das narrativas de Georges Duruy ou de Robert de Bonnières.

Sabemos, então, que nem todos os fascículos das narrativas preenchiam por inteiro o espaço geográfico do jornal destinado à publicação do romancefolhetim (ou seja, desde o início da primeira coluna até o final da última), pois determinadas obras de caráter folhetinesco ainda dividiam simultaneamente esse espaço do rodapé com algumas outras, fato que dificulta, consequentemente, a compilação dos fascículos. Há outro fator que também inviabiliza, em certa medida, a prática de recorte e costura de romances-folhetins: quando a seção Folhetim não ocupa todo o espaço do rodapé.

No dia 19 de maio de 1885, por exemplo, a disposição do vigésimo sétimo fascículo do romance de Marques de Carvalho na seção Folhetim do jornal $A$ Província do Pará restringiu-se apenas às quatro colunas do meio, de tal modo 
que tanto a primeira quanto a última não veicularam partes da narrativa do escritor paraense.

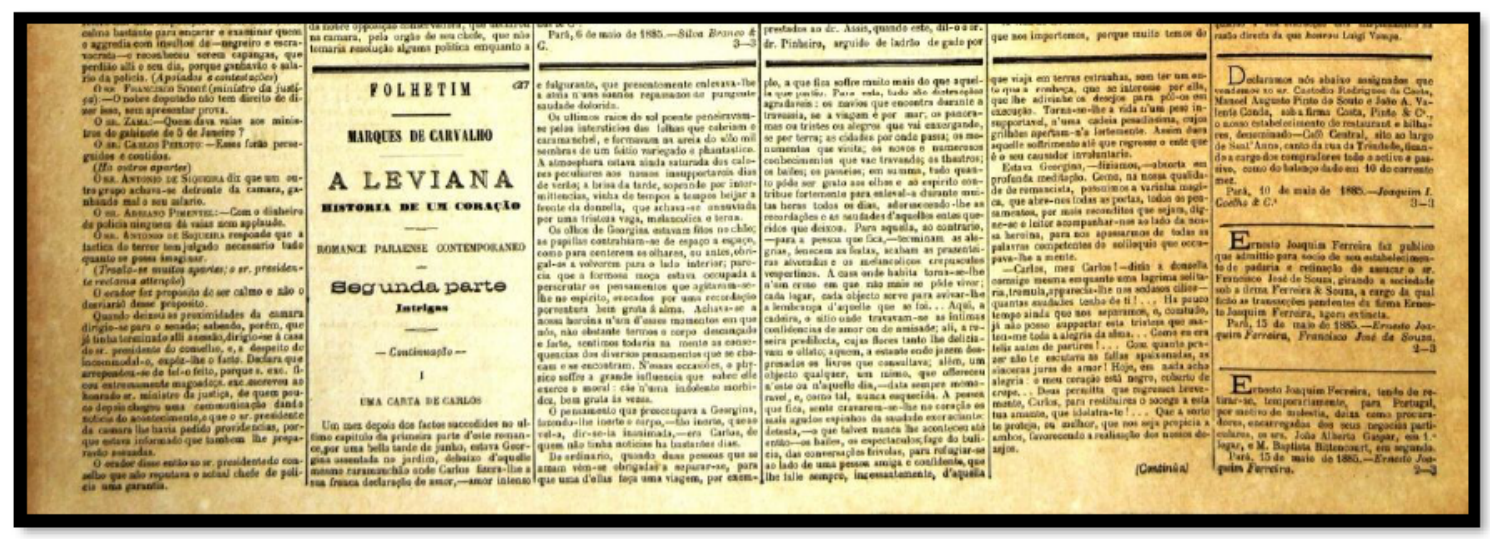

Figura 7 - No dia 19 de maio de 1885, a coluna Folhetim do jornal A Província do Pará, localizada na segunda página, onde foi publicado o romance $A$ leviana: história de um coração, de Marques de Carvalho, disposto apenas na segunda, terceira, quarta e quinta coluna. Fundação Cultural do Pará Tancredo Neves (FCPTN).

A partir da própria disposição de algumas narrativas no espaço geográfico do rodapé da página, podemos observar que não era uma preocupação do jornal A Província do Pará divulgar as narrativas na coluna Folhetim de maneira simétrica e regular para que os leitores belenenses do século XIX pudessem recortá-las, compilá-las e costurá-las, construindo, ao final, uma forma rudimentar de livro, prática de leitura, segundo Anne-Marie Thiesse, muito comum na França durante o período da Belle Époque. ${ }^{15}$

É possível afirmarmos que a maneira como essas narrativas eram dispostas entre as colunas do jornal paraense inviabilizava, em certa medida, a concretização dessa prática de leitura, pois essa folha jornalística, se tivesse com efeito essa preocupação, lançaria todos os fascículos das obras folhetinescas, sem exceção, preenchendo por completo o espaço do rodapé, iniciando o texto ficcional no início da primeira coluna e concluindo-o no final da última.

Desse modo, podemos perceber que A Província do Pará se apropriou de um recurso muito popular utilizado pela imprensa periódica francesa para alavancar os índices de venda de exemplares dos jornais - a publicação de prosa de ficção em regime seriado - , mas não se ateve à maneira como as narrativas

${ }^{15} \mathrm{Cf}$. THIESSE, Anne-Marie. Le roman au quotidian: lecteurs et lectures populaires à Belle Époque, op. cit. 
folhetinescas eram veiculadas no rodapé dos periódicos da França nem às formas de apropriação desse gênero romanesco pelos presumíveis leitores da época.

É importante frisarmos que, embora o rodapé não tenha sido criado em função da publicação de narrativas em série, os jornais que circularam no período áureo do folhetim estavam atentos às práticas concretas de leitura. Os editores, portanto, sabiam que alguns leitores - sobretudo as leitoras - recortavam, compilavam e costuravam os textos ficcionais que eram publicados no espaço do folhetim e, por essa razão, preocupavam-se com a simetria entre todos os fascículos dos romances para evitar que a fabricação de pequenos livros, que por si mesmos já são rudimentares, resultasse numa forma livresca ainda muito mais grosseira. ${ }^{16}$

No jornal A Província do Pará, por sua vez, como há no espaço do rodapé um número significativo de narrativas publicadas de forma assimétrica e irregular, podemos afirmar que a prática de recorte e costura não era muito viável para os leitores desse periódico belenense oitocentista. Desse modo, a produção de livros a partir de pedaços de jornal na capital paraense, no caso de obras como a de Marques de Carvalho, não poderia ser realizada com muito sucesso, de uma maneira minimamente convincente e exitosa, pois o produto final dessa compilação de tiras de folhas jornalísticas, com efeito, pouco se assemelharia a um livro.

Para chegarmos, porém, a um resultado mais geral e definitivo, é necessário observarmos a disposição dos romances publicados em folhetim nas páginas de outros periódicos que circularam por Belém no século XIX. Este trabalho, no entanto, já é o primeiro passo para que possamos realizar uma reflexão a respeito da prática de leitura de recorte e costura de narrativas folhetinescas na capital paraense do Oitocentos.

16 Ibidem. 